\title{
The Kinematics of the East Anatolian Fault Zone, Eastern Turkey and Seismotectonic Implications
}

\author{
Aylin Tan ${ }^{a *}$, Haluk Eyidoğan ${ }^{b}$ \\ a Institute of Natural Sciences, Main Science Branch of Geophysical Engineering, Sakarya University, 54187, \\ Sakarya, Turkey \\ ${ }^{b}$ Altıntepe, Strmakeş Sokak, No:18, D.5, Maltepe, 34840, Istanbul, Turkey. \\ E-mail address: aylin.tan@ogr.sakarya.edu.tr ${ }^{\mathrm{a}^{*}}, \underline{\text { eyidoganh @gmail.com }}{ }^{\mathrm{b}}$ \\ ORCID numbers of authors: \\ 0000-0003-0174-5146 ${ }^{a}, 0000-0003-4218-5106^{b}$
}

Received date: 20.11 .2019

Accepted date: 04.12 .2019

\begin{abstract}
One of most prominent and active faults in Eastern Turkey is the NE-SW oriented left-lateral strike-slip East Anatolian Fault Zone (EAFZ) with a length of approximately $500 \mathrm{~km}$. In this study, we have examined the recent seismicity of EAFZ that was obtained from the records of 34 three-dimensional broad-band earthquake stations established around the fault zone within TURDEP project since 2006. Further the seismicity and fault mechanism solutions of EAFZ, Eastern Turkey have been examined. The new fault mechanism solutions in addition to previously published 220 earthquakes, with a magnitude of $M_{L}=2.0$ or more were determined by a local moment tensor solution and P-wave first motion data. It was suggested that the recent tectonic deformation of EAFZ south of Türkoğlu was taken up by the left-lateral strike-slip active faults in between Amik and Adana Basins were young trans-tensional stress regime was also active.
\end{abstract}

Keywords: East Anatolian Fault Zone, Earthquake, Fault Mechanism Solution, Stress Tensor Analyses.

\section{Introduction}

The East Anatolian Fault Zone (EAFZ) is a left-lateral strike-slip fault and $500 \mathrm{~km}$ in length. The EAFZ, left lateral active strike-slip fault, extending from Karlıova (Bingöl) at the northeast through İskenderun Gulf at the southwest [1]. The fault starts at the Karlova triple junction, where it meets the North Anatolian Fault (NAF) to the NE and continues to the Türkoğlu junction (T) (Fig. 1) where it divides into several splays to the SW. It was doubtful whether the continuation of EAFZ towards to southeastern end to the Dead Sea Fault (DSF) or the Cyprus Arc (CA). Various views were proposed: a) the EAFZ continued in southwestern trending from Karlıova to north of Cyprus and was not directly connected to the DSF, b) the Türkoğlu-Amik segment (Karasu Fault Zone) was interpreted as a separate fault, c) the EAFZ continued until Samandağ (Mediterranean Sea) in splay or left-stepping pattern, d) the EAFZ was interpreted as a northward continuation of the DSF [2]. 
Cilicia region constitutes a wide left lateral shearing zone that indicates a diffuse plate boundary between the African, Arabian and Anatolian plates [3] and [4]. Stress tensor was analyzed and shows that the entire region was under control of the left-lateral strike-slip faulting with minor normal component [5]. The stress tensor for the Osmaniye region showed that the area was affected by E-W oriented extensional stress. Distribution of earthquakes has implied that the splay fault extending from (T) through Andirın to Osmaniye has appeared to be active in this century [5]. The DSF and its junction were with the southern segment of the EAFZ, despite their high tectonic activity was relatively quiescent in the last two centuries [6].

The EAFZ was among the most important active continental transform fault zones in the world as testified by major historical and minor instrumental seismicity [7] outlined the seismological aspects of the region, was outlined that the characteristics of the strong ground motion, the geotechnical characteristics of the region and the structural damages based on site assessments in Elazığ [8]. Some researchers examined that a geochemical investigation has been carried out on the gas phase associated to thermal fluids discharged along three different segments of the EAFZ running from Malatya to the Triple Junction area (Karlova) where the EAFZ and the NAFZ cross each other [9]. Further a different method, that was Artificial Neural Networks, was studied on EAFZ [10].

In this study, our aim is to examine the seismicity and fault mechanism solutions of EAFZ, eastern Turkey and whether the seismic hazard includes for segments that have been on the EAFZ. The recent seismicity of EAFZ has been monitored using the records of threedimensional broad-band earthquake stations established around the EAFZ within TURDEP Project since 2006 [11].

\section{3. Method for Stress Tensor Analysis and Fault Mechanism Solutions}

The new fault mechanism solutions of 60 earthquakes in addition to previously published 220 earthquake mechanism solutions (total 280) that occurred on and around EAFZ in the time period between 1951 and 2010 were studied to understand the principal stress field and the seismotectonic characteristics along the fault zone that was EAFZ in this study. The magnitude range of the data varied between 2.0 and 7.0. The new fault mechanism solutions in this study were determined by a local moment tensor solution (46) and P-wave first motion data (16) and had the magnitude range of $\mathrm{M}_{\mathrm{L}}=3.5$ or more (Fig. 1). Then we separated the fault zone as 14 parts that were called between D1 and D14, respectively (1 increased-stepped) (Figure 2). 


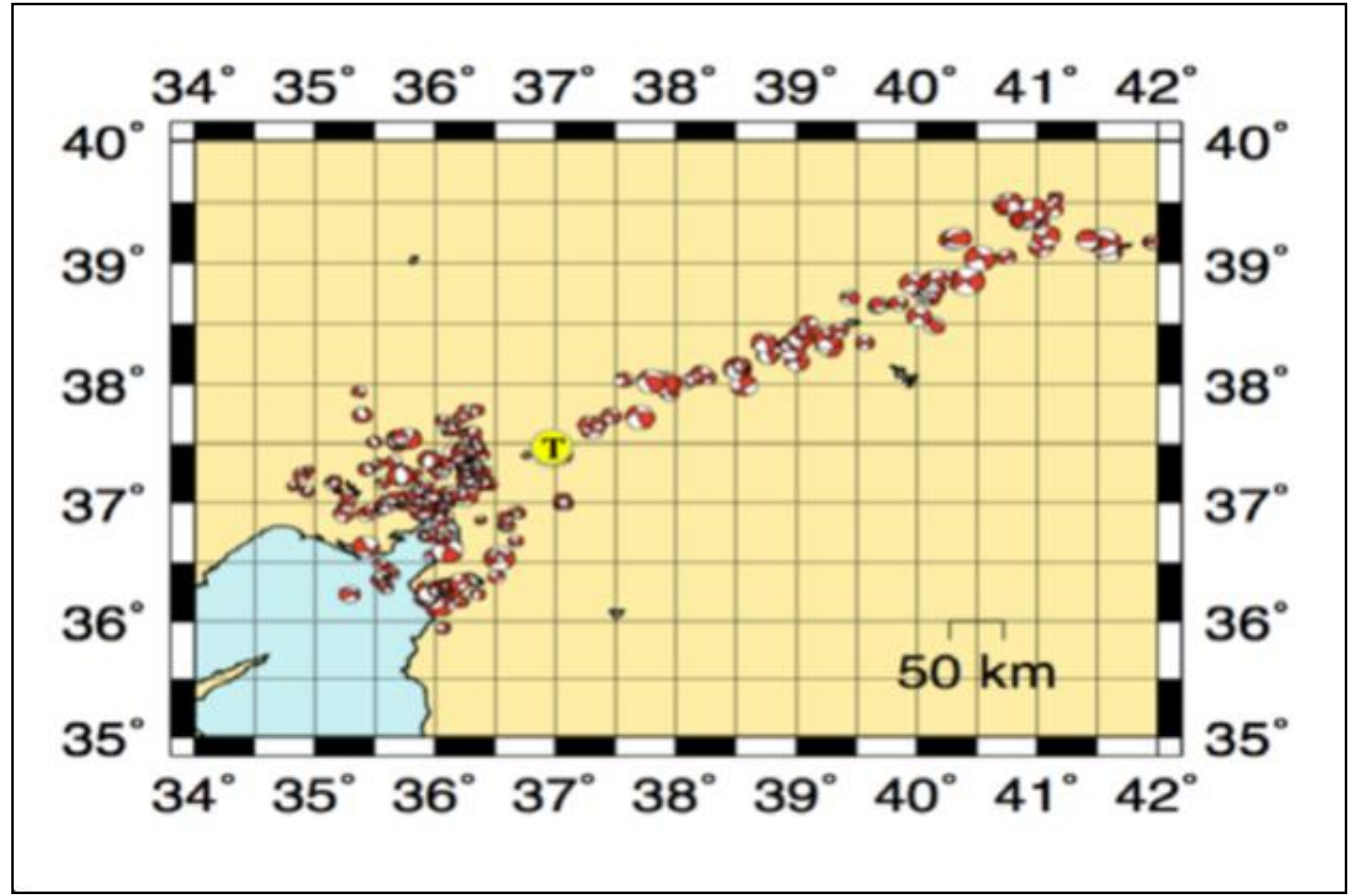

Fig.1. Fault mechanism solutions of 280 events in this study (1951-2010) (The symbol T indicates the location of Türkoğlu junction)

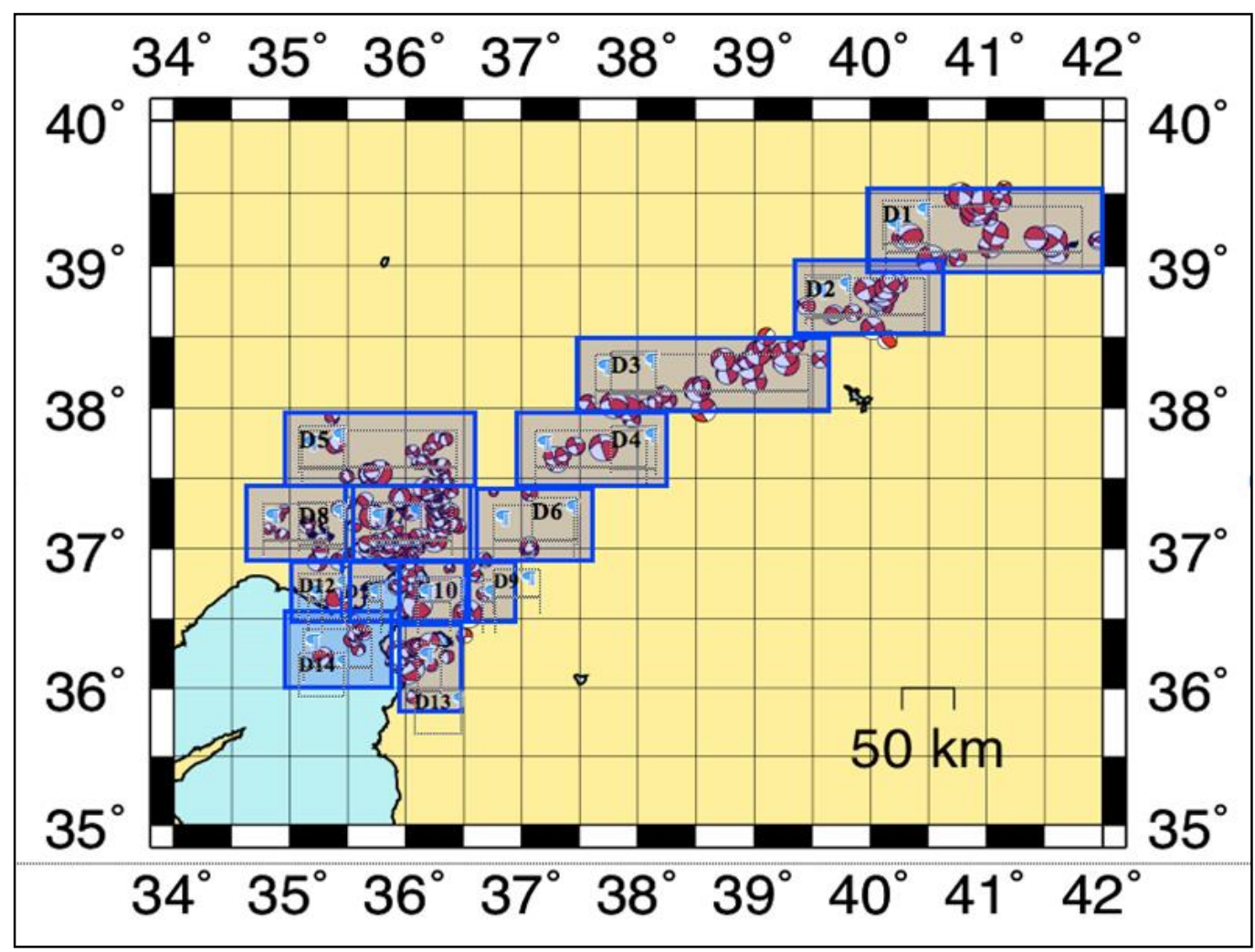

Fig. 2. Segmentation of EAFZ based on the characteristics of 280 earthquake fault mechanism solutions in the years between 1951 and 2010. 


\section{A. Tan, H. Eyidoğan}

The earthquake fault mechanism solutions were divided into sub-regions in order to analyze the tectonic stresses along the EAFZ (Fig. 2). After we separated the segments as 14 parts, we started to apply them the classical Right Dihedron Method. It was improved to estimate the range of tectonic stress regimes using the earthquakes mechanism solutions and geological field data [12]. The Right Dihedron Method was particularly well adapted for the stress inversion of focal mechanisms, as it also used two orthogonal planes to define compressional and extensional quadrants. A stress regime index R' which expressed numerically the stress regime was defined as followed:

$\mathrm{R}^{\prime}=\mathrm{R}$ when $\mathrm{S} 1$ was vertical (extensional stress regime)

$\mathrm{R}^{\prime}=2-\mathrm{R}$ when $\mathrm{S} 2$ was vertical (strike-slip stress regime)

$\mathrm{R}^{\prime}=2+\mathrm{R}$ when $\mathrm{S} 3$ was vertical (compressional stress regime)

where $\mathrm{R}$ was the stress ratio and $\mathrm{R}=(\mathrm{S} 2-\mathrm{S} 3) /(\mathrm{S} 1-\mathrm{S} 3)$. Further $\mathrm{R}^{\prime}$ ranged from 0.0 to 3.0 [13] (Fig. 3).

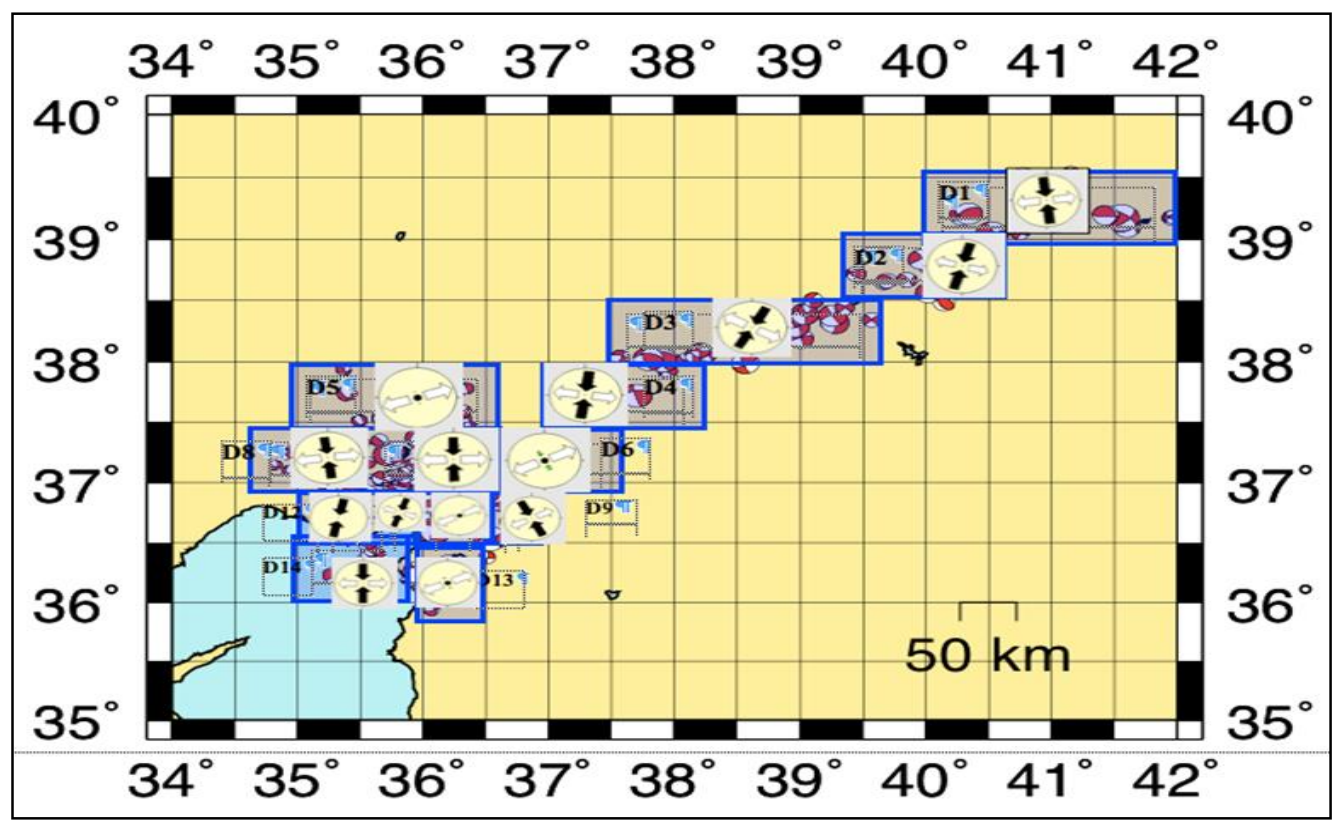

Fig. 3. Analysis using the earthquake mechanism solutions in this study (1951-2010)

The mechanism solutions of 82 earthquakes that were detected by 18 stations between 1993 and 2002 were calculated [3]. They reached the conclusion with the Cilicia region where constituted a wide left lateral shearing zone, indicating a diffuse plate boundary between the African, Arabian and Anatolian Plates (Fig. 4, Fig. 5). 


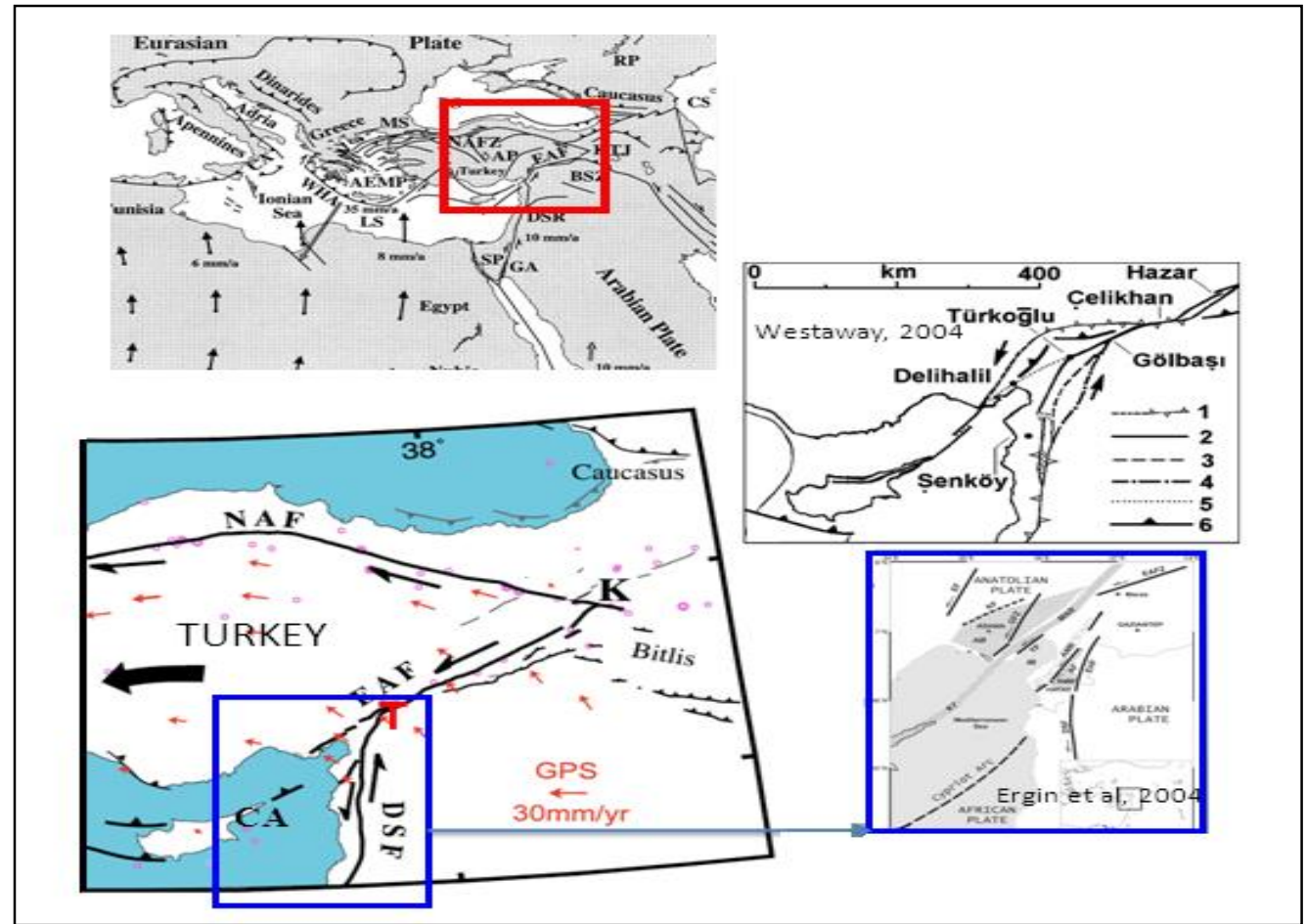

Fig. 4. Study area (Modified from [3] and [4])

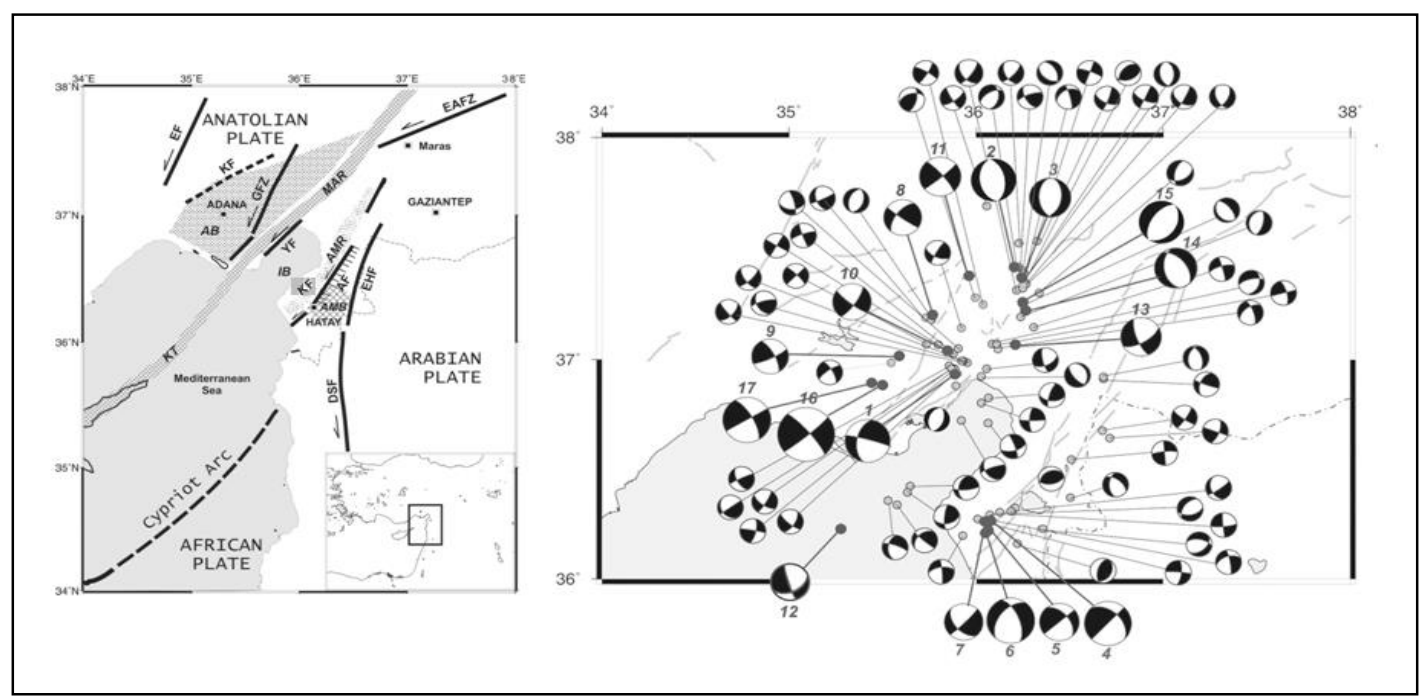

Fig. 5. Focal mechanism solutions that were studied at the study area by [3] (Modified from [3])

Collected earthquake data was analized by TUBITAK-MAM in the Cilician Region between 1999 and the first half of the 2001 (Fig. 6)[5]. 


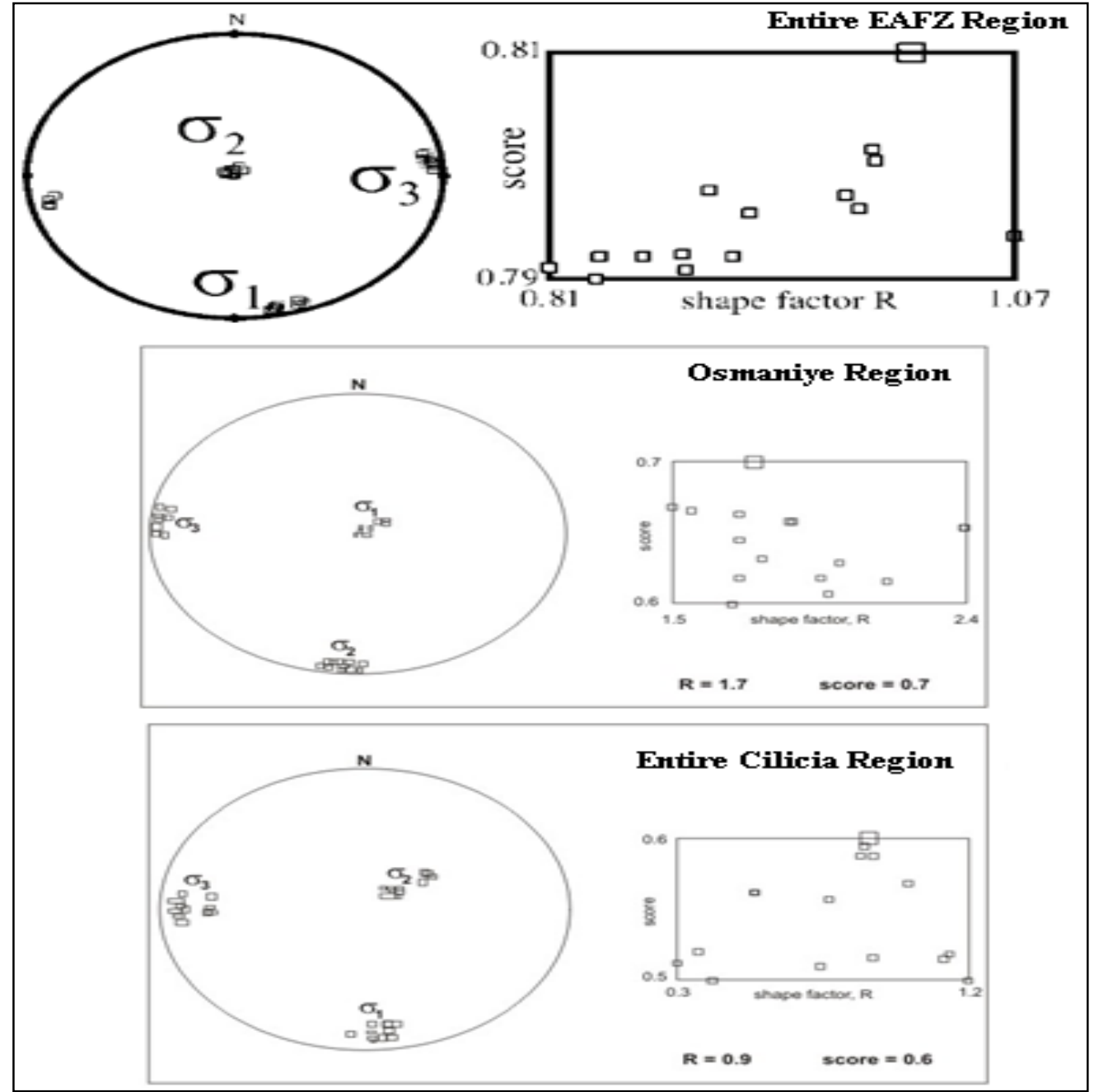

Fig. 6. Analized earthquake data that was collected by TUBITAK-MAM in the Cilician Region between 1999 and the first half of the 2001 by [5]

Stress tensors that were calculated using 59 focal mechanism solutions for the entire Cilicia region. The stress tensors showed that the entire region was under control of the left lateral strike-slip faulting with minor normal component. For the Osmaniye region the stress tensor showed that the area was affected by E-W oriented extensional stress (Fig. 7). 


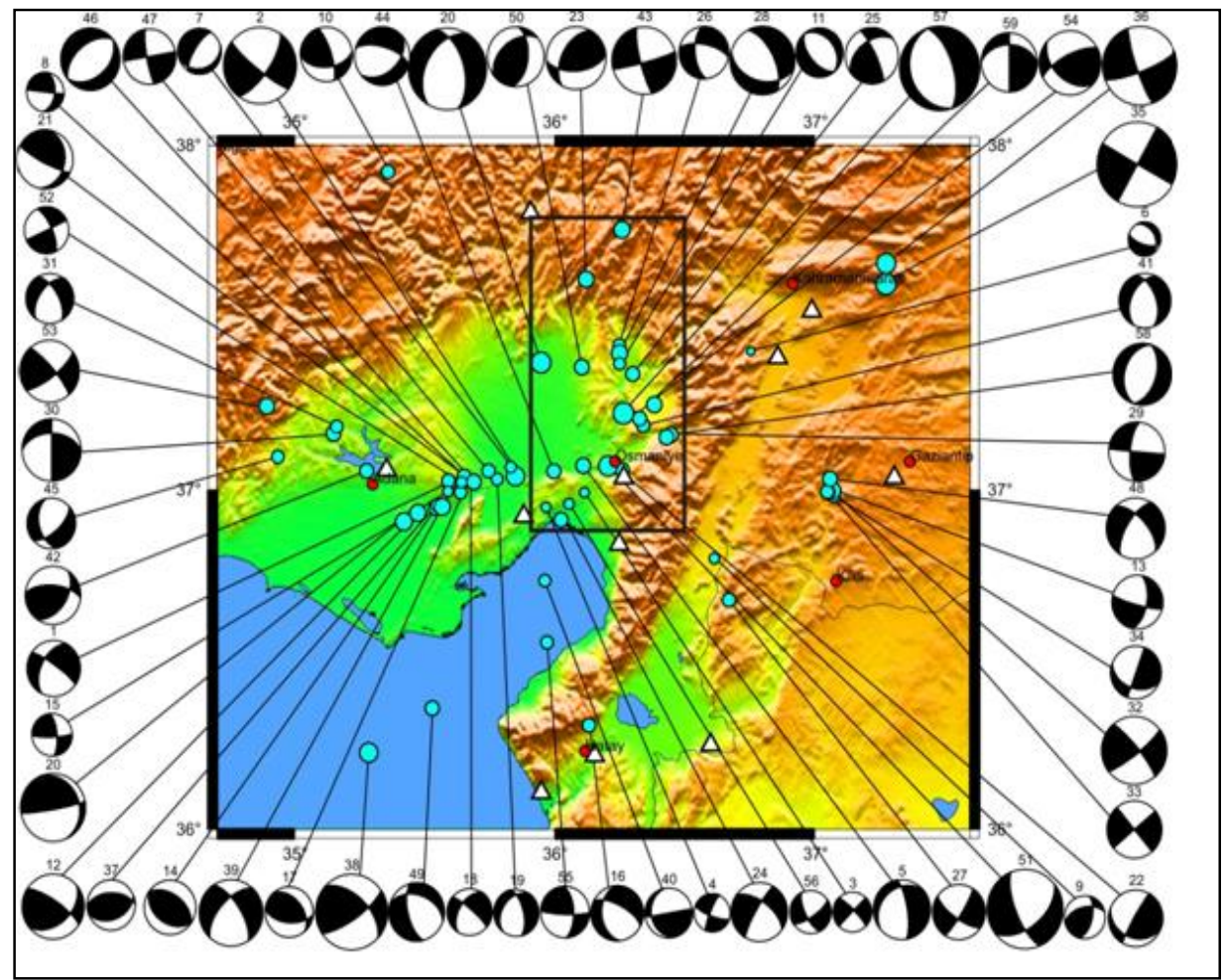

Fig. 7. The stress tensors showed that the Entire EAFZ region, for the Osmaniye region and the Entire Cilicia Region (Modified from [5])

\section{Large Earthquakes in the Historical and Instrumental Period at the Study Area}

Distribution of earthquakes implied that the splay fault extending from $\mathrm{T}$ through Andirin to Osmaniye appeared to be active in this century. Identified areas that had seismicity gaps as Elazı ̌̆-Bingöl (EB) Region and Kahramanmaraş-Malatya (KM) Region, respectively according to the Coulomb Stress Change Statement at the study area of the particular seismic risk that was one of them which might be expected to yield a large event [14]. The DSF and its junction with the southern segment of the EAFZ, despite their high tectonic activity was relatively quiescent in the last two centuries [6] (Fig. 8). 


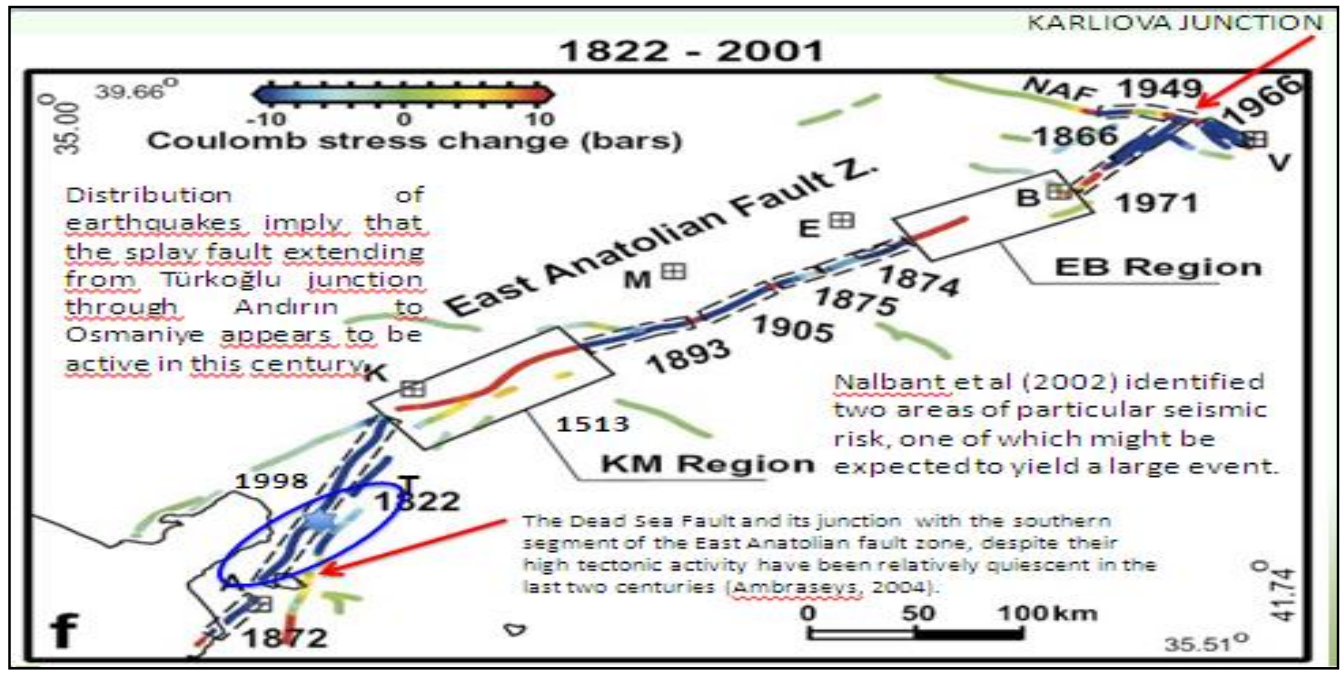

Fig. 8. Coulomb stress change was plotted as a function of distance along EAFZ. Note the spikes along the KM and EB segments at the study area (Modified from [14])

The March 8, 2010 earthquakes that hit Kovancilar and Palu districts of Elazı $\breve{g}$ province in Turkey. According to United States Geological Survey (USGS), magnitudes of these earthquakes, which caused partial or total collapse in many buildings with life losses, were 6.1 and 5.5, respectively [8]. Further, according to the historical earthquake records, the largest earthquake that affected Palu occurred in 1789 and its intensity is estimated to be 8 and it is stated that 8-10.000 or 51.000 people lost their lives as a result of the earthquake [15]. Some researchers evaluated the failures of masonry and adobe buildings during the June 23, 2011, Maden (Elazığ) earthquake. Maden was a township approximately $80 \mathrm{~km}$ away from Elazı $\breve{g}$ city in Turkey and the magnitude of the earthquake was announced as ML $=5.3$ by the Earthquake Division of the Turkish Disaster and Emergency Management Agency (DEMA) [16]. It was an earthquake that might be called as the large earthquake on the EAFZ, too. Another researcher said that recent earthquakes occurred in Bingöl on 22.05.1971, Palu on 25.03.1977, Bingöl on 01.05.2003 and Kovancilar on 08.03.2010 were quite important for Palu and its environs on the EAFZ [17]. On February 21, 2007, a moderate-sized (Mw 5.7) earthquake struck the town of Sivrice (Elazig, Turkey) located within the East Anatolian Fault (EAF) zone that formed the boundary between the Arabian and Anatolian plates [18]. Some reseachers reported that the last recorded large historical earthquake near the study area is the 1513 event, which involved surface faulting between Türkoğlu and Gölbaş1 [19].

\section{Instrumental Seismicity of EAFZ}

There have been three discussion points for determining seismicity gaps: a) the EAFZ continued southwestern trending from Karliova $(\mathrm{K})$ to Cyprus and has been not directly connected to DSF and c) the EAFZ continued until Samandağ (Mediterranean Sea) in splay or left-stepping pattern. For those reasons we obtained a seismicity map between 1973 and 2009 and determined KM and EB Regions, too (Fig. 9). 


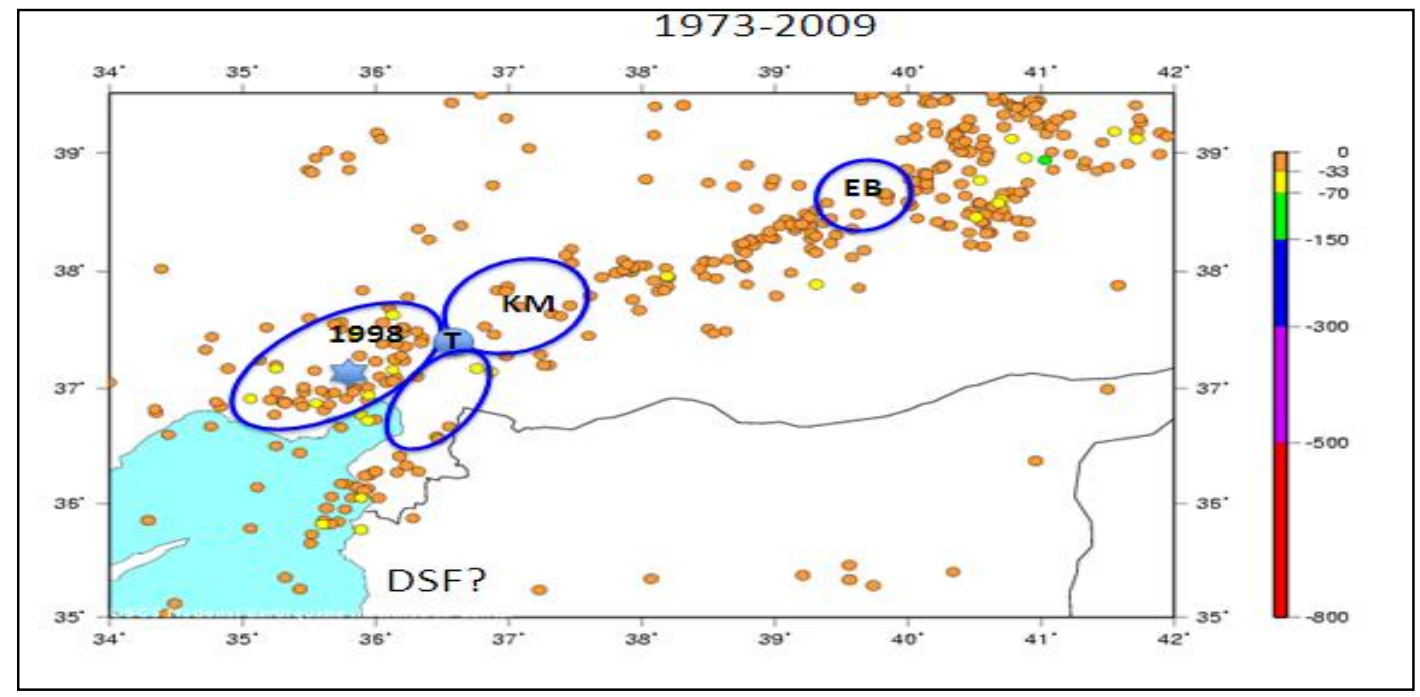

Fig. 9. KM and EB Regions, the Adana Earthquake in $1998(\mathrm{Mw}=6.2)$ in Adana, Turkey were shown as blue star and seismicity gap between EAFZ and DSF were shown as a blue ecliptic in this study. Earthquake activity was shown in the EAP Region for 50 BC-1994 AD. Circle size correlated with magnitude, color correlated with depth. Largest earthquake with associated magnitude was 7.7. Smallest earthquake with associated magnitude was 4.0. Very small circles had no associated magnitude (Modified [14]).

The recent seismicity of EAFZ had been monitored by using the records of 34 threedimensional broad-band earthquake stations which were established around the EAFZ within TURDEP Project since 2006 [11]. The coordinates of the error margins of recently relocated epicenters were less than $\pm 2 \mathrm{~km}$. Some epicenter clusters displayed parallel and conjugate fault activity to EAFZ. The EAFZ has had high seismicity for near present time. We can see them on Fig. 10-11-12 and 13, respectively below.

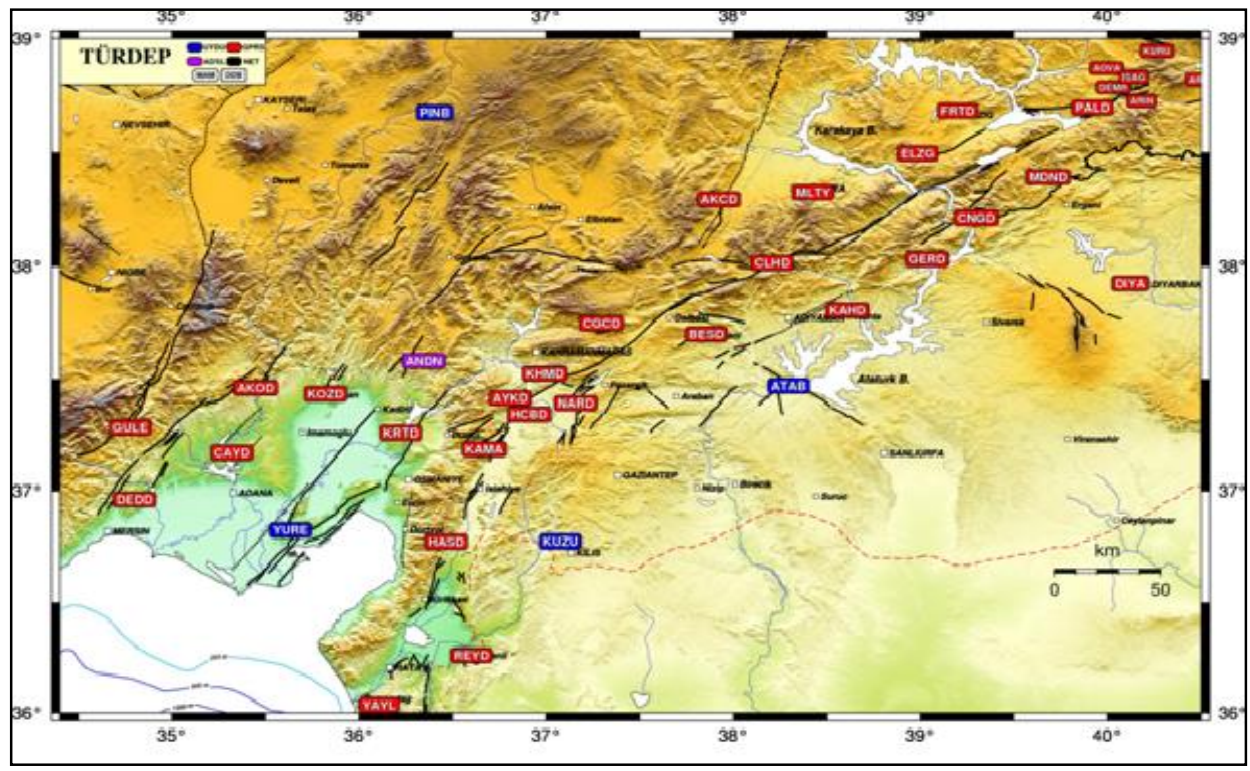

Fig. 10. The earthquake stations at the study area that were located by different institutes [11] 


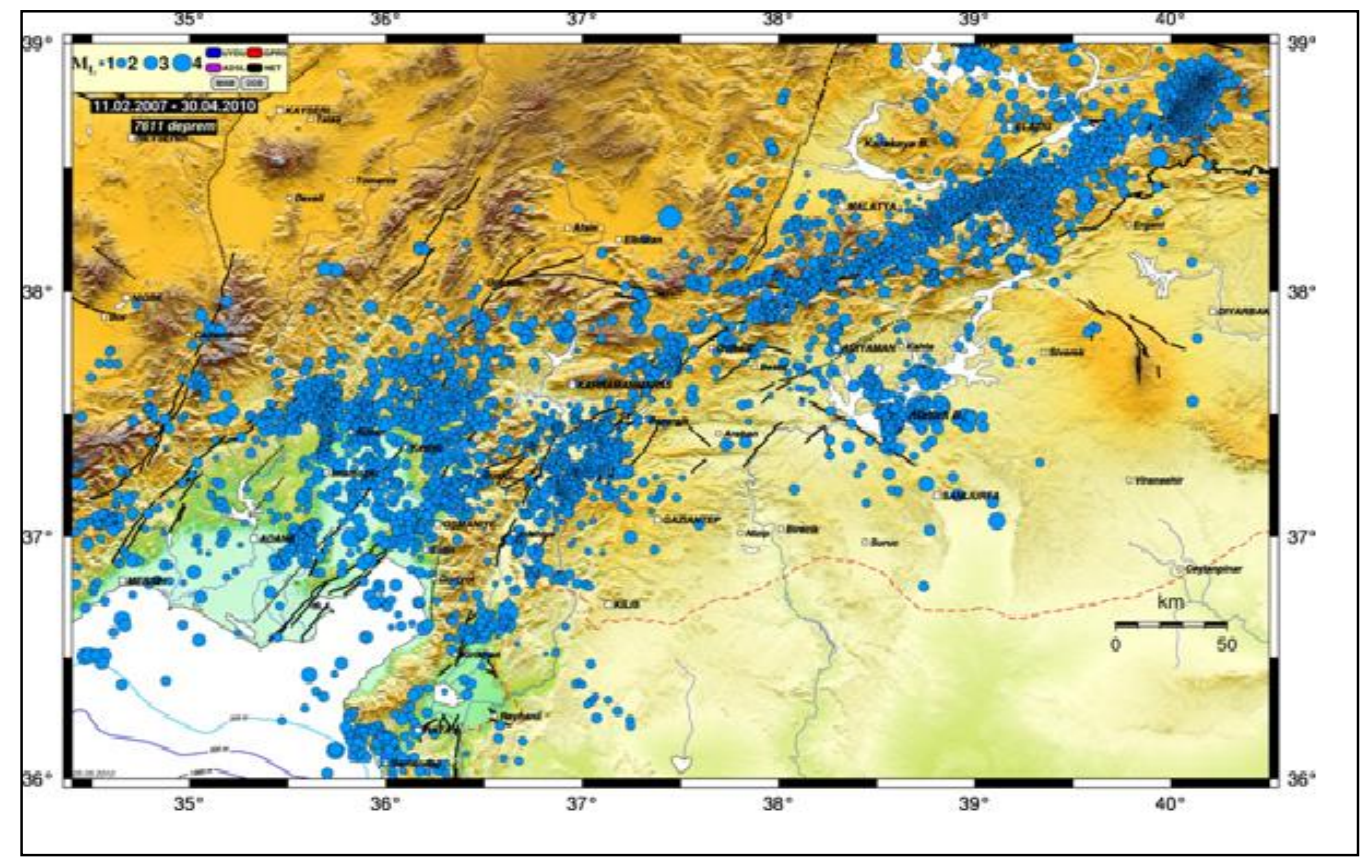

Fig. 11. Earthquakes that were classified according to magnitude scales (ML=1.0, 2.0, 3.0 and 4.0) between 11.02.2007 and 30.04.2010 at TURDEP Project TUBITAK-MAM, Turkey [11]

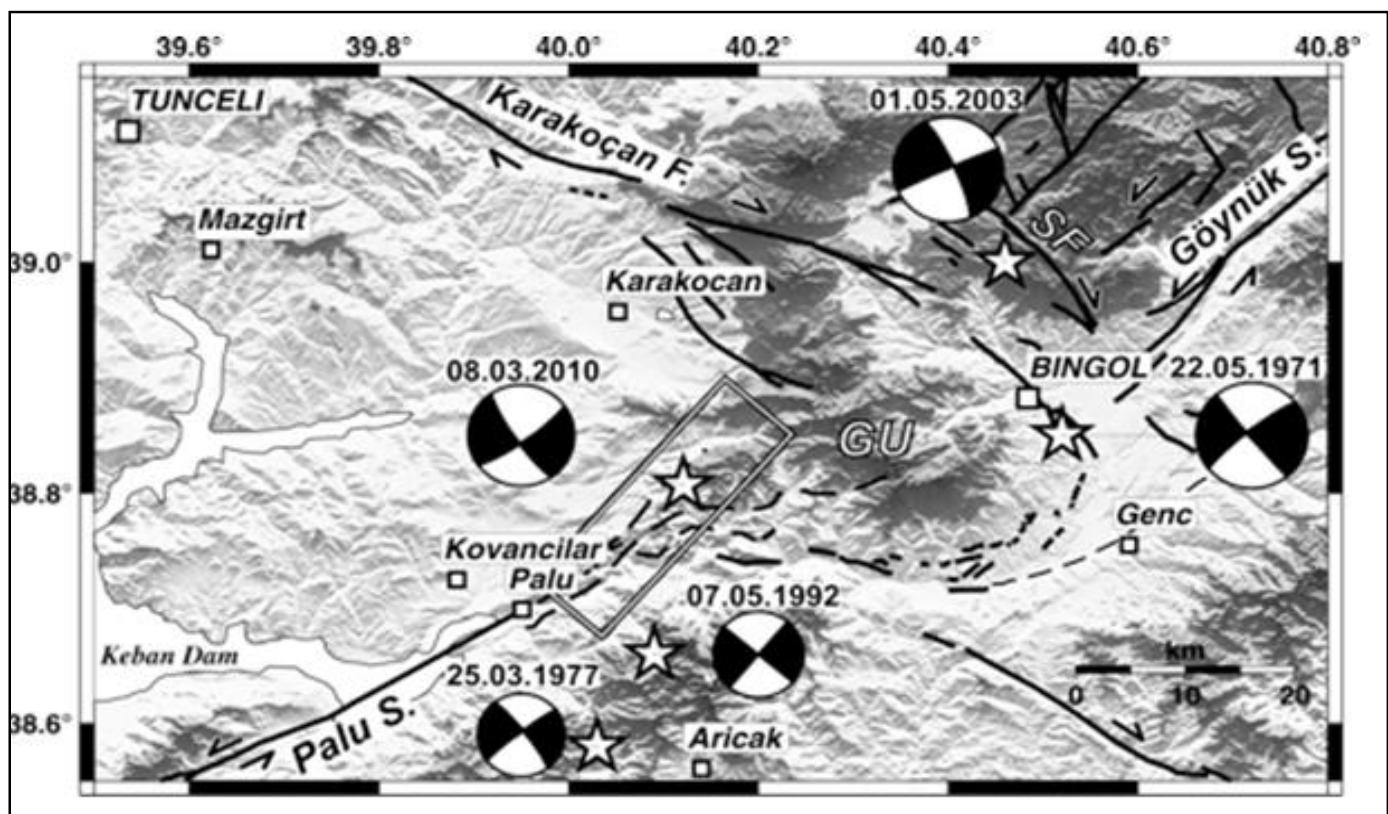

Fig. 12. Focal mechanism solutions of some major and strong earthquakes in vicinity of the study area (Modified from TURDEP Project, TÜBİTAK-MAM [11]) 


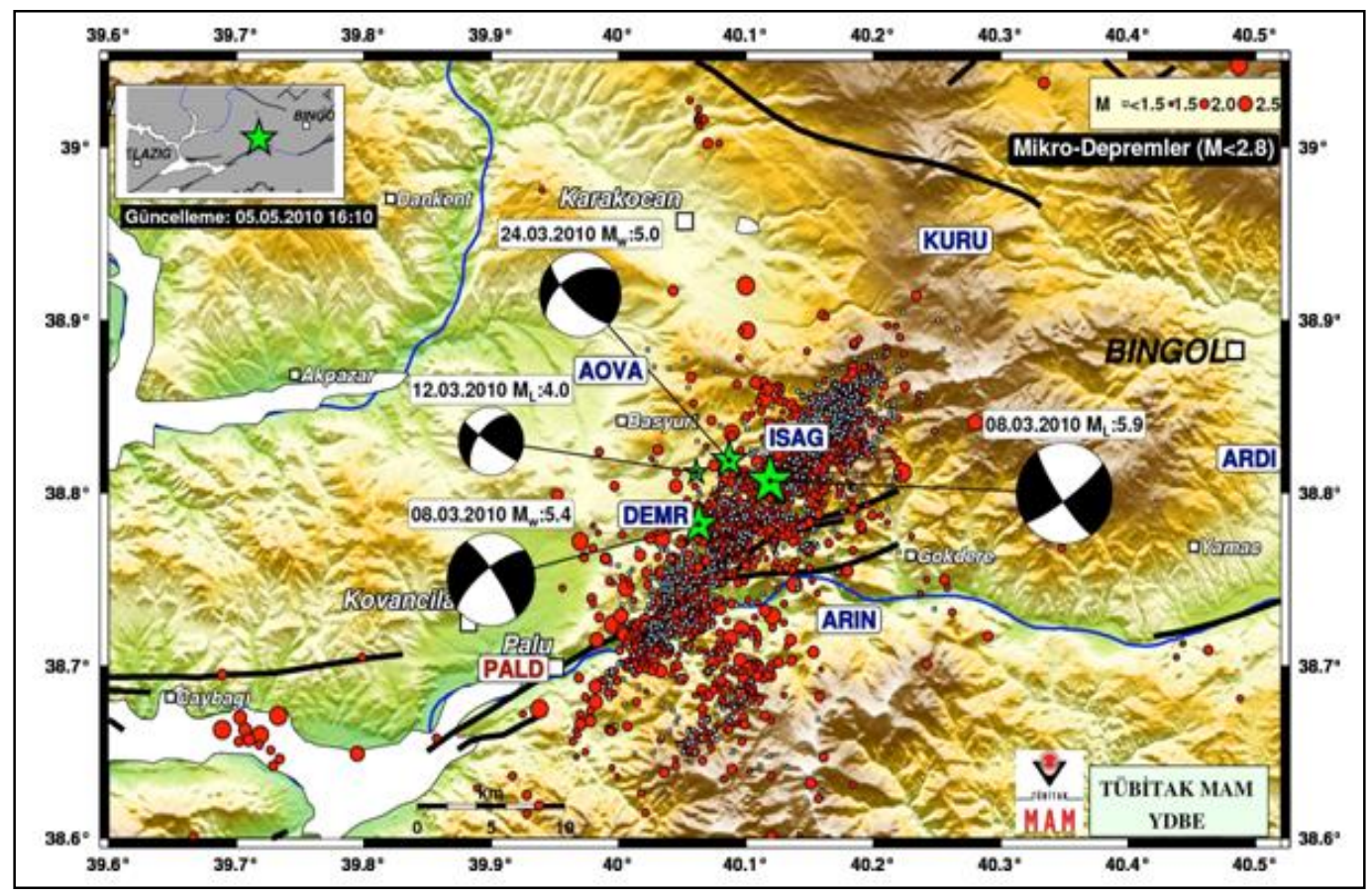

Fig. 13. Southwestern part of region EB has produced an earthquake with $M=6.0$ on March 8 , 2010 (Modified from TURDEP Project, TÜBİTAK-MAM [11])

\section{Results and Discussion}

1. A pure strike-slip stress deviator characterized by an approximate $\mathrm{N}-\mathrm{S}$ trending $\sigma 1$ and an approximate E-W trending $\sigma 3$ axis for the area between Karlıova and Türkoğlu along the EAFZ

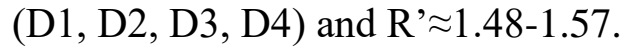

2. A pure extensional and qblique extensive stress deviator characterized by an approximate NE-SW trending $\sigma 3$ for the area between Türkoğlu and northern tip of DSF along western segment of EAFZ (Maraş and Karasu Basin) (D6, D10, D13) and R' $\approx 0.45-1.73$.

3. A pure strike-slip stress deviator characterized by an approximate $\mathrm{N}-\mathrm{S}$ trending $\sigma 1$ and an approximate $\mathrm{E}-\mathrm{W}$ trending $\sigma 3$ axis for the area west Türkoğlu-Osmaniye zone (D7, D8, D9, D11, D12, D14) and $\mathrm{R}^{\prime} \approx 1.38-1.67$.

4. Cilicia region constituted a wide left-lateral shearing zone that indicated a diffuse plate boundary between the African, Arabian and Anatolian Plates.

5. The present day stress regime has been extensional and/or trans-tensional in the southern region of the EAFZ between Türkoğlu and Antakya.

6. The strand of the Karasu fault zone in this region has formed a linkage between DSF and EAFZ.

7. The recent tectonic deformation of EAFZ south of Türkoğlu were taken up dominantly by the left- lateral strike-slip active faults in between Amik and Adana Basins that were young 
trans-tensional stress regime has been also active. Further the present seismic quiescence was compared with the past activity (paleoseismic and historic) and it indicated that the EAFZ might be "locked"' and accumulating elastic strain energy but could move in the near future [7]. There are the seismic gaps on the EAFZ as we explained in this study, too.

8. Left lateral strike-slip character of EAFZ was more dominant at west of Maraş-Antakya, South of T implying that the continuation of EAFZ towards DSF further Türkoğlu has been debatable based on the recent fault mechanism solutions.

\section{Acknowledgments}

We thank to TÜBITAK-MAM because of their supports of knowledge TURDEP Project TÜBİTAK-MAM, Turkey during this study.

\section{References}

[1] Köküm, M. and Özçelik, F. 1789 Palu Depremi, Fırat University Harput Applied and Research Center, International Palu Symposium Proceedings, 11-13 October, 329-337, 2018.

[2] Rojaya, B., Heimannb, A. and Toprak, V. Neotectonic and volcanic characteristics of the Karasu Fault Zone (Anatolia, Turkey): The transition zone between Dead Sea transform and the East Anatolian fault zone, Geodinamica Acta, 14, 1-17, 2001.

[3] Ergin, M., Aktar, M. and Eyidoğan, H. Present-Day seismicity and seismotectonics of the Cilician Basin: Eastern Mediterranean Region of Turkey, Bulletin of Seismological Society of America, 94, 3, 930-939, 2004.

[4] Westaway, R. Kinematic consistency between the Dead Sea Fault Zone and the Neogene and Quaternary left-lateral faulting in SE Turkey, Tectonophysics, 391, 1-4, 203-237, 2004.

[5] Tan, A., Eyidoğan, H., Tan, O., Pabuccu, Z., Yörük, A. and Geçgel, V. The new fault mechanism solutions of East Anatolian Fault Zone, Eastern Turkey and Seismo-Tectonic Implications, In Proceedings ESC 2010, 6-10 September 2010, Montpellier, France, p. 7, 2010.

[6] Ambraseys, N. N. The $12^{\text {th }}$ century seismic paroxysm in the Middle East: A historical perspective, Annuals of Geophysics, 47, 733-758, 2004.

[7] Çetin, H., Güneyli, H. and Mayer, L. Paleoseismology of the Palu-Lake Hazar segment of the East Anatolian Fault Zone, Turkey, Tectonophysics, 374, 163-197, 2003.

[8] Celep, Z., Erken, A., Taşkın, B., and İlki, A. Failures of masonry and concrete buildings during the March 8, 2010 Kovancilar and Palu (Elazı $\breve{G})$ Earthquakes in Turkey, Engineering Failure Analysis, 18, 868-889, 2011. 
[9] Italiano, F., Şaşmaz, A., Yüce, G. and Okan, O. O. Thermal fluids along the East Anatolian Fault Zone (EAFZ): Geochemical features and relationships with the tectonic setting, Chemical Geology, 339, 103-114, 2013.

[10] Külahçı, F., İnceöz, M., Doğru, M., Aksoy, E. and Baykara, O., Artificial neural network model for earthquake prediction with radon monitoring, Applied Radiation and Isotopes, 67, 212-219, 2009.

[11] http://www.mam.gov.tr/english/YDBE/projeler/Makes-Major.html

[12] Delvaux, D. and Sperner, B. New aspects of tectonic stress inversion with reference to the TENSOR program, NIEUWLAND, D. A. (Ed.) New insights into structural interpretation and modelling, Geological Society, London, Special Publications 212,75-100, 2003.

[13] Delvaux, D., Moeys, R., Stapel, G., Petit, C., Levi, K., Miroshnichenko, A., Ruzhich, V. and Sankov, V. Paleostress reconstructions and geodynamics of the Baikal region, Central Asia. Part II: Cenozoic rifting. In: Cloetingh, S., Fernandez, M., Munoz, J.A., Sassi, W. and Horvath, F. (Editors), Structural controls on sedimentary basin formation, Tectonophysics, 282, 1-38, 1997.

[14] Nalbant, S. S., McCloskey, J., Steacy, S. and Barka, A.A. Stress accumulation and increased seismic risk in Eastern Turkey, Sci. Lett., 195, 291-298, 2002.

[15] Köküm, M. and Özçelik, F. A case study on reassessment of historical earthquakes: 1789 Palu (Elazığ) Earthquake, Eastern Anatolia, Turkey, Bulletin of the Mineral Research and Exploration, 161-?, 2020 (Uncorrected Proof).

[16] Sayın, E., Yön, B., Calayır, Y. and Karaton, M., Failures of masonry and adobe buildings during the June 23, 2011 Maden-(Elazığ) earthquake in Turkey, Engineering Failure Analysis, 34, 779-791, 2013.

[17] Sunkar, M., Major Earthquakes in The Historical and Instrumental Periods on Palu (Elazığ) and Effects on Settlements, Firat University Harput Applied and Research Center, International Palu Symposium Proceedings, 11-13 October, 297-309, 2018.

[18] Şentürk, S, Çakır, Z., Ergintav, S. and Karabulut, H., Reactivation of the Adıyaman Fault (Turkey) through the Mw 5.7 2007 Sivrice earthquake: An oblique listric normal faulting within the Arabian- Anatolian plate boundary observed by InSAR, Journal of Geodynamics, 131, 101654, 2019.

[19] Yönlü, Ö., Altunel, E., Karabacak, V. and Akyüz, H., Evolution of the Gölbaşı basin and its implications for the long-term offset on the East Anatolian Fault Zone, Turkey, Journal of Geodynamics, 65, 272-281, 2013. 